\title{
How can an ecological perspective be used to enrich cities planning and management?
}

\author{
Como uma perspectiva ecológica pode ser usada para enriquecer o \\ planejamento e gestão das cidades?
}

Natalie Rosales

Consejo Nacional de Ciencia y Tecnología (CONACYT), El Colegio Mexiquense A.C., Toluca, Mexico

\begin{abstract}
This conceptual article presents a comprehensive overview of principles, new urban descriptors and analysis methods that provide relevant ecological information, which can be fully incorporated into the planning process, by connecting ecological perspectives to planning and management issues. Section one summarizes the different notions of ecological urbanism and explores what concepts and basic assumptions can constitute a guide to implement an ecological perspective into urban planning. Section two covers what frameworks exist for planning and managing the city under an ecological perspective; and what methods and tools are being used by different stake holders to implement an ecological vision today. As a synthesis, the paper suggest that ecological urbanism applies through six concepts (ecological networks, nestedness, cycles, flows, dynamic balance and resilience), which can be covered by three principles: I) an eco-systemic understanding and management of the city; II) a bioregional governance; III) an ecologically balanced planning. By doing so, this piece of work builds conceptually and practically a frame towards the transformation of current planning and management practices outlining clues for reinterpreting strategies to re-signify and re-conceptualize the existing dichotomous relationship between city-nature, environment-society, while strives for a new understanding of the way we inhabit the habitat.
\end{abstract}

Keywords: Urban planning \& management. Ecological perspectives. Sustainability.

\section{Resumo}

O presente artigo conceitual expõe uma visão geral dos princípios ecológicos, novos descritores urbanos e métodos de análise que podem ser integralmente incorporados no processo de planejamento, conectando informações ecológicas relevantes com as implicações dessa perspectiva ambiental no planejamento e na gestão das cidades. A primeira seção resume as diferentes noções de urbanismo ecológico e explora que conceitos ecológicos e pressupostos básicos podem constituir um guia para implementar uma perspectiva ecológica no planejamento urbano. A segunda seção indica que marcos existem para o planejamento e a gestão da cidade sob uma perspectiva ecológica; quais métodos e ferramentas estão sendo usados por diferentes partes interessadas em implementar uma visão ecológica hoje. Como síntese, o documento sugere que o urbanismo ecológico aplica-se por meio de seis conceitos (redes ecológicas, aninhamento, ciclos, fluxos, equilíbrio dinâmico e resiliência): i) compreensão

NR is a sustainability scientist, PhD on Sustainable Development, e-mail: nrosales@cmq.edu.mx, natalie_rp2000@yahoo.com.mx 
e gestão ecossistêmica da cidade; ii) governança biorregional; iii) planejamento ecologicamente equilibrado. Assim, o trabalho fornece um marco conceitual e prático que permite a transformação das práticas atuais do planejamento e gestão urbana, delineando novas ideias para reinterpretar, reconceituar e ressignificar a relação dicotômica existente entre cidade-natureza, ambiente-sociedade, enquanto se esforça para alcançar uma nova compreensão da maneira como habitamos o hábitat.

Palavras-chave: Planejamento urbano. Perspectivas ecológicas. Sustentabilidade.

\section{Introduction}

Grasping ecological perspectives for their incorporation into urban planning

The twentieth century witnessed the way in which the science of ecology was transferred to the social sciences and through them, influenced the use of analogies and naturalistic images to city planning (Light, 2009), but also developed a contrasting approach to study the ecology of the city (Pickett et al., 2010). In this way, the study of "the ecology of the city" and "the ecology in the city" was synthetized in a single global and comprehensive vision (Marzluff et al., 2008).

Under this context, many researchers, practitioners, and critics have explored alternative and radical approaches between ecology and architecture, urban design, landscape, planning, and urbanism contributing to the theory and practice of ecological urbanism.

Departing from visionaries- such as the geographer Patrick Geddes (1915) who viewed each city and its surrounding countryside as an evolving organic whole whose future plan should be based on an understanding of its natural and cultural history; the critical thinking of Lewis Mumford (1968), one of the first to ask questions on the ecology of urbanization and promote an integrative approach to cities and their regions; McHarg (1967) whose point of departure was the natural environment as a prerequisite for planning and design, and advocated a survey on ecological inventory; Spirn (1984) who demonstrate how cities are part of the natural world and therefore can be designed in concert with natural processes; Sim Van der Ryn \& Cowan (1996) who advocated for designs that minimizes environmentally destructive impacts by integrating itself with living processes. Following this tendency there are planners such as Calthorpe \& Van der Ryn (1986) who linked sustainability principles to ecosystem services and Beatley (2010) who calls for putting the bio-philia hypothesis and developed a green urbanism approach.

As a result, the development of an ecological perspective into urbanism has gained importance as it its connected to multiple interrelated movements: ecological design, industrial ecology, deep ecology, and the so called sustainable development paradigm.

In recent years, scholars applying a multiplicity of old and new methods, tools, and techniques such as Owen (2009) who recognizes that right densities and teeming cities can contend the environmental problem; Forman (2014) who combines urban planning and ecological science in examining urban regions, Mostafavi \& Doherty (2010) who in there compendium of ecological urbanism define a new sensible approach, identifying drivers and constraints for its materialization; and Reed \& Lister (2014) who through a review and update of where are ecological thinking and theory now, use advances in ecological research and modeling, in social theory to find new ways of unifying ecology and design, have provided enormous contributions to advance the theory and practice of ecological urbanism.

This review of literature reflects the way in which different approaches to design and practice when wedded with the insights of ecology, especially from environmental planning and landscape ecology (with an emphasis on biodiversity); and different environmental disciplines such as climatology, hydrology, geography, psychology, history, and art (Spirn, 2013), can lead to the development of shared notions to comprehend patterns and flows that connect to nature; work with urban structures and components as organic elements of a larger ecosystem; and address a new ethics and aesthetics of an urbanism that is not unharmonious with the process and facts that sustain life (Mostafavi \& Doherty, 2010).

Yet, according to Mostafavi ecological urbanism must be supplemented with advances from a host of other fields and define the conditions of governance 
under which it could operate, that would result in a more cohesive planning model.

As a researcher and practitioner integrated into the dialogue of city-building I have witnessed how these ideas may have had limited impact on mainstream planning practices. Cities show no evidence of becoming, substantively more sustainable -ecological, social, or economic wise - (Rosales, 2015) and planning still needs to do more than introduce some isolated notions of ecology thinking and greening urban strategies.

Despite practices around the world that prove the viability of its implementation ecological urbanism remains as an ideal of how cities can become greener, there is still a need to continue to blur disciplinary boundaries and scale up.

Thus, I argue that the advocacy of an ecological urbanism and a sustainable scenario needs to be founded on basic ecological concepts and principles, all reflected in each stage of urban planning and management, which should be supported by decision making tools, methods and innovative ways to respond to challenges confronting our cities and regions and; implemented by institutions that are flexible and can adapt quickly to changes (UNEP-IETC, 2003).

In this direction, the goal of this paper is to explore which general understandings and assumptions about ecological concepts and principles, grounded on ecological urbanism and strong sustainability perspectives, can be fully incorporated into urban planning and management; which frameworks exist for planning and managing the city under an ecological perspective; and which methods and tools are being used by different stake holders to implement an ecological vision today.

These insights will provide a synthetic and valuable framework for alternative multi-scalar strategies, sensitive to the spatial dimension of urban ecological processes in order to overcome mainstream planning based approaches. Approaches which have so far ignored key issues such as: the interactions between components of urban habitats, environmental limits of the territory, how cities metabolizes nature, urban-rural flows, ecosystem services, environmental justice, and the broader ecological impacts cities infringe on larger territories.

The exploratory literature review methodology framed leading questions to produce knowledge on which ecological concepts and basic assumptions implicit in the different approaches can help to implement an ecological perspective into urban planning. It also identifies existing frameworks for planning and managing the city under an ecological perspective; and methods and tools that are being used by different stake holders to foster an ecological vision today.

Based on an extensive search and analysis of case studies on topic areas, in universities, and public institutions' web sites and books, I was able to identify relevant publications and practices to inform this piece of work and support my proposal for a set of general understandings and assumptions about ecological concepts and principles that can bond ecological perspectives with planning and management issues.

\section{Approaching the city from an ecological perspective: basic principles and concepts}

A city can be considered as a heterotrophic artificial ecosystem (Odum, 1983), which could be analyzed with the same parameters of measurement and on the same terms that natural ecosystem are. Therefore, ecological thinking applies to cities and other urban ecosystems. Unlike natural ecosystems however, urban ecosystems are a hybrid of natural and man-made elements whose interactions are affected not only by the natural environment, but also culture, personal behavior, politics, economics and social organization (UNEP-IETC, 2003).

The urban ecosystem contains both individual and nested systems from three spheres: (a) the natural environment, (b) the built environment and (c) the socio-economic environment. So, urban areas are equally biological, social, built and geophysical (McDonnell et al., 2009). This means that in an urban ecosystem, humans influence ecological factors (plants, air, soil, animals), and human decisions (where and how to build houses, parks, highways, schools) are influenced by ecological factors.

Consequently, an approach to the ecology of urban areas should consider the city as a physical fact rather than as an abstract system (Feria \& Santiago, 2009) taking into account two main aspects: the city - ecosystem, understood as an homogeneous and global entity (Terradas, 2001); and the diverse and heterogeneous urban ecosystems that make up complex's ecological landscapes, also understood as habitat mosaics (Bettini, 1998).

Applying this approach of urban environments to planning and management calls the incorporation of 
basic principles of ecology to the understanding of cities. According to Fritjof (1997) there are basic principles that could be called principles of ecology, principles of sustainability, principles of community, or even the basic facts of life, which can create communities that are compatible with ecological processes. These principles are; ecological networks, nestedness, cycles, flows, dynamic balance and resilience. As it could be observed, these principles are also consonant with the general notions of ecological urbanism scholars' uphold. So, I will built up my proposal to shape our cities planning and management through an ecological perspective on these basic assumptions about ecosystems and how they function.

Ecological networks. The biotic interactions in an ecosystem, in which species (nodes) are connected by pairwise interactions (links) can be represented throughout ecological networks. This relation between species that live together in a community; specifically, the effect an individual of one species may exert on an individual of another species (Tomera, 2001).

Nestedness. Nature is made up of systems that are nested within systems. Each individual system is an integrated whole and, at the same time, part of larger systems. Changes within a system can affect the sustainability of the systems that are nested within it as well as the larger systems in which it exists (Marten, 2008).

Cycles. Members of an ecological community depend on the exchange of resources in continual cycles. Ecosystems recycle locally, converting mineral nutrients into the production of biomass, and on a larger scale they participate in a global system of inputs and outputs where matter is exchanged and transported through a larger system of biogeochemical cycles. Particulate matter is recycled by biodiversity inhabiting the detritus in soils, water columns, and along particle surfaces (Orr, 1992). In this way, cycles within an ecosystem intersect with larger regional and global cycles.

Flows. Ecosystems are interconnected systems where matter and energy flows and is exchanged as organisms feed, digest, and migrate about. Each organism needs a continual flow of energy to stay alive (Devall \& Sessions, 1985). Ecosystems maintain themselves by cycling energy and nutrients obtained from external sources (e.g. at the first trophic level, primary producers; plants, algae, and some bacteria, use solar energy to produce organic plant material through photosynthesis). The constant flow of energy from the sun to Earth sustains life and drives most ecological cycles. In each transfer, some energy is lost as heat, requiring an ongoing energy flow into the system.

Dynamic balance. Ecosystems are organized in a state of stability where species coexist with other species and with their environment. Ecological communities act as feedback loops, so that the community maintains a relatively steady state that also has continual fluctuations (Marsh, 1999). This state of dynamic equilibrium within a community of organisms in which genetic, species and ecosystem diversity remain relatively stable, does not mean that no changes ever occur. Gradual ecological changes (disturbances) through natural succession occur, causing a disruption in the balance of an ecosystem.

Resilience. All ecosystems have the capacity to cope with disturbance or stress and return to a stable state following a perturbation. The amount of disturbance that an ecosystem could withstand without changing self-organized processes and structures (defined as alternative stable states) has been defined as resilience (Gunderson, 2000). The concept is consistent with the notion that ecosystems are complex, dynamic and adaptive systems that are rarely at equilibrium; they continually change in unpredictable ways in response to a changing environment, so the definition recognize the presence of multiple stable states (or stability domains), hence resilience is the property that mediates transition among these states (Holling, 1973). This dynamic balance provides resiliency to cope with disturbance or stress and return to a stable state (Bettini, 1998).

These basic ecological concepts can be applied to enrich cities planning and management and set the ground for wider transformations towards a sustainable urbanization by three principles: i) an eco-systemic understanding and management of the city ii) a bioregional governance iii) an ecologically balanced planning.

\section{Applying ecological thinking to cities planning and management}

\section{Working on an eco-systemic understanding and management of the city}

Understanding and managing the city from an ecological perspective implies a conceptual switch from urban analysis, where the unit of examination 
is the city, to approach it as an ecosystem. In ecology, the idea of system is key to understand organisms, their interactions with one another and with the environment, and the transformations of matter, energy and information (Chapin et al., 2002). A system consists of parts, but the system has properties that emerge from the interaction of the parts. Urban ecosystems contain organisms, physical conditions and entities, and the interactions among the biological, social physical and built components (Forman, 2008). In a similar way to ecosystems, cities and their components can be examined independently, but the parts cannot be separated from one another, as they are linked to larger systems.

From this perspective cities can be consider as open systems whose performance is possible from external inputs to meet the basic needs of production and consumption (Rees, 1996). Understanding urban space from this point of view leads to compare a city to an organism, in their common trait of the demand for food and the deposition of waste on the environment (Grimm et al., 2000). Also implies to comprehend the relationships of the structure and functioning of urban ecosystems (through ecological networks); the influence of these patterns in the flows of water, energy, nutrients and biota (Castro, 2002); the links between the city's environmental impacts and its resilience, and the well-being of its citizens.

But, how does this principle of an eco-systemic understanding and management of the city could work in practice?

A better understanding of the cities ecological urban structure and functioning can be fully incorporated into planning by data analysis of bio physical flows and environmental information about cycles and interactions in the urban ecosystem, the exchanges and transformations of energy, water, carbon and pollutants.

A practical methodological approach to do it is by undertaking urban metabolism analysis (UMA). The urban metabolism approach is related to the ecological concepts of flows, cycles, and nested systems, and can provide planners the environmental and economic functioning of the city and its interrelations with the surrounding areas and the challenges the city faces in terms of current imbalances (identifying whether energy and materials or water are used efficiently; if levels of environmental degradation are decreased; or the level of exhaustion of their nearest resources). This integrated information enables an ecological management of how cities metabolize nature, as it helps the design of appropriate strategies to slow exploitation, set goals for dematerialisation (consumption of fewer materials) and decarbonisation (consumption of less carbon), which are necessary to close ecological cycles and feedback loops.

One example of how urban resource consumption metabolism has been used to guide spatial planning policy is the Best Foot Forward analysis of London. The project was funded as part of Biffa Waste Management's scheme, with the support of the Chartered Institution of Wastes Management, the Greater London Authority, and the Institution of Civil Engineers. Introducing the report, then Mayor of London Ken Livingstone highlighted how the resulting information on London's metabolism would be used to guide spatial planning policy as well as specific environmental strategies on air quality, biodiversity, energy, noise, and waste management (Best Foot Forward Ltd., 2002).

One more practical approach to advance an eco-systemic understanding and management of the city, specifically related to the concepts of networks and nested systems, is to include information about the ecosystems services. Identifying the benefits that nature provides, understand the value of these benefits and prioritize which ecosystem services are most relevant in the specific urban environment context can enhance well-being in cities by managing scarcity, guiding land-use decisions and safeguarding biodiversity.

There are different approaches to ecosystem services, which can be employed within planning systems to make this work in practice. Haines-Young \& Potschin (2009) identify three:

- Place-based approach focused on identifying and evaluating the interrelationships between all services in a defined geographical area;

- Habitat approach focused on units of habitat, and linking ecosystem services with biodiversity action planning processes;

- Services approach focused on the ecosystem services themselves. 
These approaches can be accomplished by qualitative and quantitative assessment and monetary valuation methodologies depending on the different perspectives. Environmental services assessment can be used to analyze not only the environmental benefits services provide, but also how are they affected, or impacted, by policy issues the city intends to implement. The city of Baltimore, for example, has used valuating ecosystem services to support urban forest initiatives. Baltimore's program for the coordination of all tree plantings by city agencies, non-profit organizations, neighborhoods, and community associations, has estimated that its 2.8 million trees store 527 tons of carbon and remove 244 metric tons of ground-level ozone annually. It also estimated that its trees reduce energy costs citywide by $\$ 3.3$ million a year (Treebaltimore, 2016).

This evaluation assessment of the economic and environmental benefits has been used to develop a series of urban forest programs to increase tree canopies, and raised awareness that urban trees are a vital part of a functioning ecosystem, which can significantly reduce storm water runoff, absorb dangerous chemicals and other pollutants in the soil, and store the pollutants or make them less harmful.

To support the evaluation treebaltimore used an analysis tool for urban forest managers (i-Tree Streets software) that based on tree inventory data quantifies the dollar value of annual environmental and aesthetic benefits: energy conservation, air quality improvement, CO2 reduction, storm water control, and property value increase (i-Tree, 2016). This is an illustration of how new ecological descriptors and analysis methods can be incorporated into urban planning to support an ecological planning and management.

Once it is understood the ecological urban structure there is the need to manage urban flows and accomplish a circular metabolism. Closing the loops on resource flows and increasing resource efficiency and recycling processes requires a transformation in the way users are involved, technology is developed and organizations are managed (Makropoulos et al., 2012). For instance, managing urban flows through the reincorporation of treated water into rivers and water catchment areas; treatment schemes of sewage at the local level enabling its re-use; food production within the city through the promotion of urban agriculture; promoting the use of zero-emission green technologies in waste management; and reducing energy consumption by incorporating low-carbon technologies and more sustainable mobility patterns, have shown a great potential to close feedback loops.

There are different pilot cases around the world which illustrate how a perspective to manage urban flows can be implemented. For an overview of urban water cycles for example revised Makropoulos et al. (2012).

Another example to advance a circular metabolism can be found in transforming small parcels of vacant land into areas of production. Urban agriculture initiatives have risen in popularity due to an interest in local food sources, farmers' markets and as well as urban land's close proximity to markets, so different cities worldwide have recently incorporated a specific land use for urban agriculture zones into their zoning.

In Mexico City for instance since 2000, the Government has paid more attention to agriculture, in order to maintain the environmental services and ensure local food supply. Peri-urban agriculture is practiced in municipalities of medium and high altitude and low population densities. Generally, the plots have surfaces between 1 and 3 ha and are used for the production of corn, amaranth, prickly pear, oats, peas, fruit trees and vegetables. This peri-urban and suburban agriculture is supported by legal planning instruments (General Ecological Program) and by a specific land use zoning (FAO, 2015).

Working on moving from the current administrative political division to boundaries that are defined by natural processes and systems

Cities do not have a different ecology from its surrounding countryside. They are part of larger ecologically defined regions that also reflect human identity with the local regional landscapes, a sense of place, in addition to ecological processes operating across those landscapes (Zipperer et al., 1997).

In the broadest sense, urban ecosystems comprise not only city cores, suburban areas, sparsely settled villages connected by commuting or utilities to more densely settled and thoroughly built up areas that are always in contact with the adjacent ecosystems watersheds, and eco-regions (Wittig, 2009).

But often, urban and rural are conceptualized in opposite terms. On the one hand, the population density and the economic activities linked predominant criteria for defining the urban opposed to rural, 
which is characterized by low population density and economic activities based on agriculture. Both are profoundly interconnected an ongoing part of larger ecological regions and landscapes, who are linked through a complex economic, political and environmental social fabric.

Still, territorial boundaries and demarcation of bioregions not normally coincide with the current administrative political division for purposes of development policies.

This is a serious obstacle to maintain the integrity of biological communities, habitats and ecosystems in the region; sustain essential ecological processes, such as nutrient cycles, and migration flows; and include human communities in the management, use and understanding of biological resources (Taylor, 2000).

According to Allen (2002) urban ecological planning and management demands a conceptual and methodological approach to move away from the physical definition of cities (understood as clearly delimited geographic and administrative entities) to a broader understanding of the articulation of complex patterns of settlement where the flows do not know of jurisdictional boundaries.

In this way, planning by ecoregions, or areas that are unified in climate, topography, geology, and vegetation and distinct living communities is more sensible ecologically than just planning within politically drawn boundaries such as states or provinces.

Therefore city planning and management as a nested system, where relations between demographic flows, resources, and information, entails creating governance structures that can address bioregional issues such as water, food, waste, energy, transport, biodiversity, as well as urban rural flows (Newman \& Jennings, 2008).

Grounded of this perspective, bioregionalism becomes a strategic process that allows formulating policies, making simultaneous use of different geographical and institutional scales to support the goal of accelerating change toward improved well-being for nature and society (Warren, 2013).

\section{But, how does this focus on a bioregional governance could work in practice?}

Engaging in comprehensive, adaptively managed change improving society's overall opportunity to achieve sustainability at a scale is not possible within a single community effort. Large-scale social change will only materialize where people share common concerns, goals, and core values around sustainability.

According to Bernard (2014), because of the implementation of bioregionalism is a different way of considering problems and solutions involving collective decision-making in the management and distribution of resources, to advance this framework some changes need to be done in our governance schemes. This implies a political restructuring based on self-sufficiency which means to develop local capacities to manage our own ecoregions; staying within the local or regional carrying capacity; the regulation of patterns of consumption and restoration of resources, reconnecting us with the consequences of our decisions.

Bioregionalism has few established paradigms or methods to create this political and institutional framework in which government, community, corporations and other non-state and private interests can be encouraged to cooperate for the sustainable development of the territory. Miller (1999) identifies six basic elements of this approach:

- The scale and geographical scope;

- Communities with interests in question;

- Science, technology and information;

- Institutional mechanisms and governmental arrangements;

- Incentives and enabling policies;

- Adaptive management, monitoring and evaluation.

Based on this, bioregionalism approach is a useful strategy to shape our cities from an ecological perspective because can assist in focus our attention on those aspects that are crucial to environmental sustainability, such as considering the connectivity of nature including human activity across adjacent and even more distant ecosystems; fitting the landscape scale of linked ecological processes and services; taking into account biodiversity, urban equipment, sports and recreation in a management context on both human culture and environmental attributes.

It can help for example, to understand the relevance urban fringes take in managing flood risk and the effects of climate change; the role of green infrastructure (metropolitan urban agriculture scale) in the urban metabolism; and matching social and 
ecological functions as a unit of governance. Ensuring water supply, fostering food security within the context of flow of nutrients and prevention of soil degradation. Or the eradication of rural poverty by establishing ecological and cultural corridors with multiple objectives, including to promote regional and national integration of local communities.

There are interesting examples to illustrate how this principle can be implemented. Cuba, for example, has put into practice the notions of bioregionalism since 1997 through Watershed Councils. This administrative structure based on a physical geographic unit delimitation has served for the realization of actions within a complex interactive system in which the protection and management of the environment is linked to economic and social development, putting ecological notions beyond the provincial political and administrative divisions.

The basin as the basic watershed unit has allowed a balance of energy flows in the territory through an integrated environmental management of water, soils, forests, human settlements, industrial development, agricultural activities and cultural heritage (CIGEA, 2016).

The potential of bio-regions as an instrument for sustainable development policy is closely linked to the value of GIS tools, and can be helpful in shaping our cities from an ecological perspective. For instance, Nature Conservancy produced a practical approach and tools of eco regional assessment to the application of landscape-scale and conservation planning, by using a GIS.

The Environmental Atlas of North America allows the visualization of environmental information in North America through geo-referenced maps and data, to present and analyze information and establish priorities for conservation actions, in a bioregional context.

As presented in Figure 1, the different maps show the ecological regions of North America: areas of general similarity in ecosystems and the type, quality and quantity of environmental resources. This GIS of

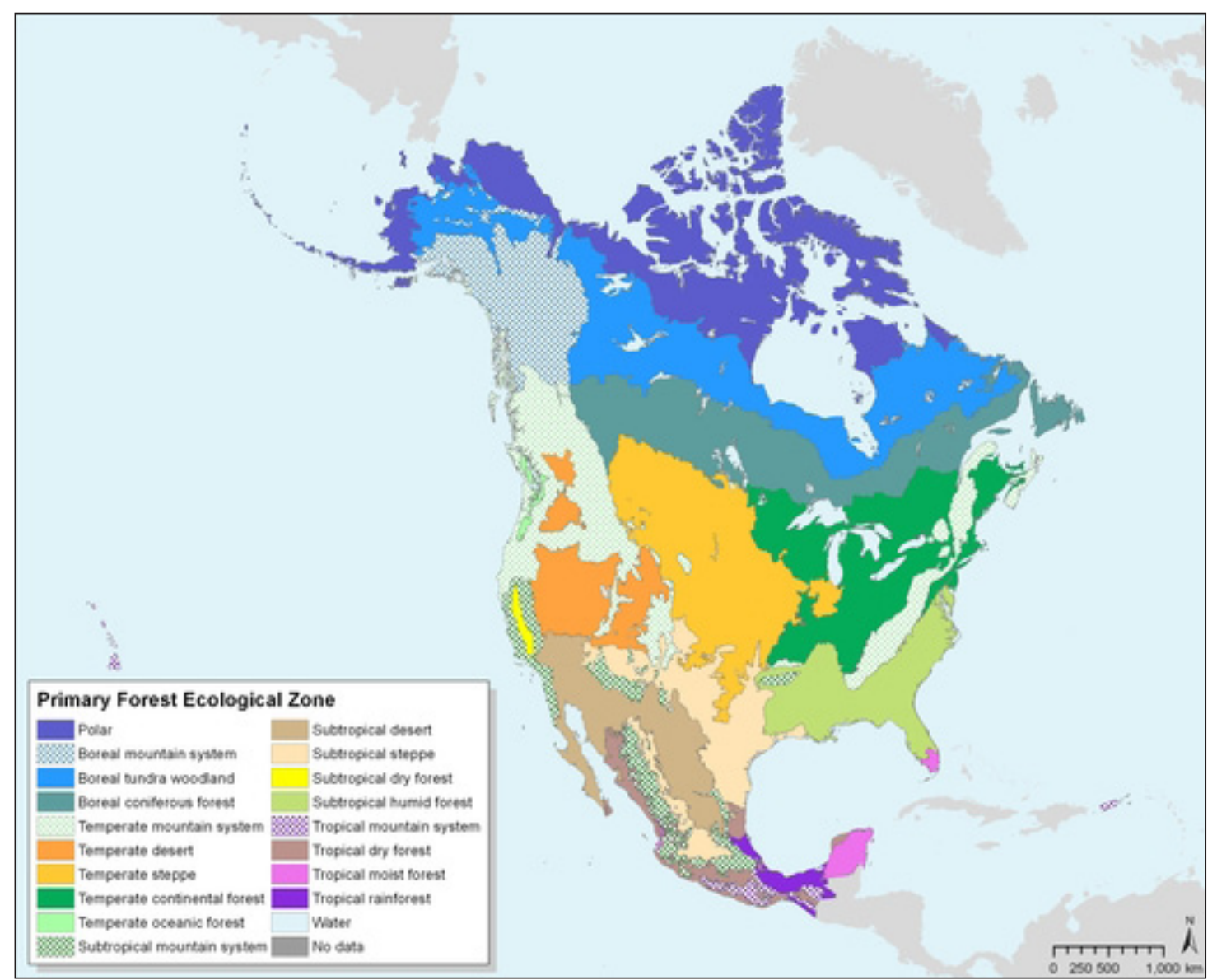

Figure 1 - The Environmental Atlas of North America Source: CEC (2016). 
the ecological regions serve as a spatial framework for research, evaluation, management and monitoring of ecosystems and the elements that compose them.

Also facilitates reporting on the state of the environment, inventories and assessments of environmental resources; the establishment of regional objectives of resource management and the formulation of biological criteria and water quality standards (CEC, 2016).

\section{Working on an ecologically}

balanced urban planning

Ecological urbanism recognizes the scale and scope of the impact of ecology, which extends beyond the urban territory. Cities, can no longer be thought of only as a physical artifact; they must be environmentally balanced taking into account the dynamic relationships, both visible and invisible, that exist among the various domains of a larger terrain of urban as well as rural ecologies (Mostafavi \& Doherty, 2010).

In view of that, urban sustainability grounded on strong ecology perspectives also emphasizes that a sustainable city can only be ecologically balanced if it achieves self-sufficiency. This means if the city is capable of achieving a dynamic balance, in which the interactions of matter and energy between the natural world and the urban ecosystem factors are manifested in the form of feedback processes, self-control and balance (Tjallingi, 1995).

In current urban dynamics cities are major importers of materials providing food, clothing, shelter, energy and industrial needs, mostly drawn from outside the metropolitan boundaries, while they export degradation to their hinterland. This basic dependency on the wider world, is seldom discussed or analyzed in urban planning strategies. So, contrasting the demand for natural capital -that represents the amount of biologically productive land and sea area necessary to supply the resources for a human population consumes, to assimilate associated waste - with the local ecological capacity to regenerate, is therefore fundamental to assess an urban development which is conditioned by the carrying capacity, and not only by urban population demands.

This focus on an urban planning that addresses the problems that occur within the city limits and its effects on the regional and metropolitan areas, while takes over the responsibility for the local management of its resources can tipping the balance and address sustainable urban and regional development aspects such as: the depletion of groundwater sources and the failure in the treatment and discharge of waste water, accumulation of solid waste, air pollution, degradation of the environment and the loss of biodiversity.

\section{But, how can this principle of an ecologically balanced planning can work in practice?}

Assessing the impact of the activities taking place within the urban ecosystem on human health, vegetation, biodiversity, cultural and natural heritage, to balancing the economic advantages of production, trade and transport activities in the city, in opposition to the environmental costs due to the degradation of natural, cultural and human values, can be done by linking urban flows information to the use of environmental indicators.

In addition to well-known concepts and methodologies for evaluating environmental impact such as the ecological footprint, carbon water and energy footprint assessment, caring capacity, ecological overshoot just to mention the more relevant, there are other indicators with a focus on taking into equal account all species impacted by urbanism and equal access to ecological benefits that can be introduced in urban development plans.

This includes: the percentage of population within a few hundred feet of a green space, percentage of city land covered by vegetation, number of green design features (i.e. rooftop gardens, use of solar energy, and water run-off systems), average portion of the day spent outside by residents, number of trips made on foot, percent of residents who can identify local flora and fauna, and priority given to nature conservation by local government.

For instance, an environmental indicator developed by a collaborative process among different social actors; farmers, industrials, scientists, engineers, civil society, government officials, ecologists, social scientists and communities can be helpful for a genuine environmentally balanced management. Such is the case of the water extraction indicator developed by WWF-Mexico in 2004, under the framework of the project on New Models of Water Management. 
The project, executed in three basins in the country: the Conchos River, the River San Pedro Mezquital, one of the last free-flowing rivers to the sea, and the basins of the Copalita-Zimatán-Huatulco rivers, establishes an ecological balance water extraction (ecological cuadal) to assess how much water should the community draw for their activities and how much should be saved to support ecological basic functions (WWF, 2011).

Through an agreement between indigenous communities interests (Zapotecs \& Tepehuanes) who identify and protect the river to fulfill their duties and the site as a religious place, ecologists who proposed to maintain the caudal river with a depth of 1-2 meters, and engineers who stablished the technical viability, the environmental indicator has been a useful management tool to stablish an ecological balance of the water extraction limit.

There are also intervention tools closely linked to local policies and management of the water cycle, recycling of urban waste, or control air quality, such as the Local Agenda 21, Environmental Profiles, Strategic Environmental Assessment (SEA), Environmental Budgeting (Ecobudgets), which can provide a common understanding of how the city's economic sectors interact with the environment in terms of resources and hazards, and ensure that the environmental impact of policies and programmes in a development strategy (for example, a City Development Strategy) are identified, assessed, and mitigate (UNEP-IETC, 2003).

There are many examples how these instruments promote a more ecological planning and management which takes into account and reduces possible environmental impacts. For an overview see Jones et al. (2006).

An ecologically balanced planning is also related to the concepts of dynamic balance and resilience. These ecological notions put in the spotlight to look at the many impacts of disasters and the need to build long-term capacity of communities to absorb disturbances, change, reorganize, adapt and cope with uncertain risks, such as climate change (Folke et al., 2002).

Effective tools and methodologies that combine land use planning with ecosystem management approaches to disaster risk reduction, watershed management (e.g., coastal zone management); urban landscape design; green and blue infrastructure; and environmental buffers can then promote a dynamic balance of urban ecosystems making them resilient.
Among the approaches to support this principle we can mention: environmental risk assessment (EnRA); environmental technology assessment (EnTA), risk-based land use planning; urban ecosystem management; urban upgrading; community and stakeholder participation; disaster management systems; data gathering, analysis, and application; and risk financing and transfer approaches (Grimm et al., 2008).

An example of how these instruments can be implemented and support an ecological planning and management by protecting valuable habitats and relevant ecological areas is the case of Prince Edward Island's Buffer zones.

This buffer zone, shown in Figure 2, is a regulation instrument to protect the area alongside watercourses and wetlands and has been useful for protecting Prince Edward Island's water resources by filtering and assimilating contaminants from surface runoff water (Canada, 2016).

Other example of how ecological concepts are related and can be implemented into planning instruments which promotes a vision of city as an urban ecosystem and supports local biodiversity and network green spaces rather than isolated green areas spots in the city, promoting a balanced planning is the Barcelona Green Infrastructure and Biodiversity Plan 2020.

The Plan conceives urban green as a green infrastructure and an inherent part of the city that provides environmental and social services and thereby increases the quality of life of the city's residents. The infrastructure plan sets a model of an urban green network and a city where green elements are not just ornamental accessories. Functional network of green infrastructures are composed by

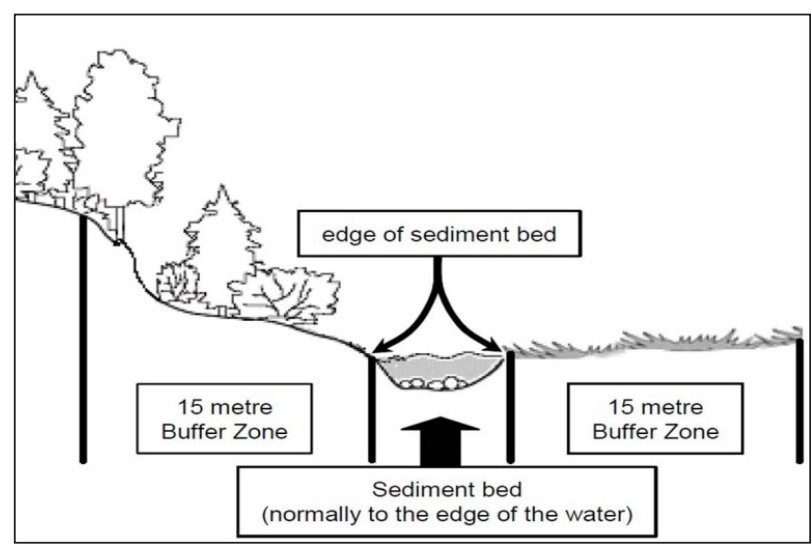

Figure 2 - Bufferr zones

Source: Canada (2016). 
urban green corridors, and the re naturalisation and revitalization of varying kinds and sizes areas, ranging from unoccupied plots to green roofs and balconies (Ajutament de Barcelona, 2011).

\section{Final remarks}

To advance urban sustainable transformations we need to better understand the environmental context of cities, and foresee the potential of urban planning as an ongoing process of converting the relations between society-nature to work on an alternative project of urban environments integrated to the natural ecosystems that sustain them.

Urban developments or redevelopments should be guided by a sustainable planning and a management vision that promotes interconnected spaces, livable communities that protect historic, cultural, and environmental resources, and a balance between built and natural systems. Which also means responsible growth and development strategies that are broader in vision and more regional in scale.

As the article outlines, implementing this ideas necessitates a very different epistemology from the current approaches of the way we understand cities, plan and manage our urban environment. In this sense, ecological perspectives that comprehends that the entire urban area is relevant to ecological processes, including reciprocal relationships among organisms, the physical environment, resources, waste streams, environmental regulating factors, human individuals, households and institutions, can help to build this new epistemology and change our praxis.

As shown in the different examples, the insights of ecology presented through basic principles and its implication into planning has the potential to produce models, metaphors, and concepts which allow the reformulation, development, implementation and use of new methods and techniques to enable urban planners, analyze and evaluate information at different stages of the planning process, in terms of sustainability.

Therefore, the set of ecological principles about how ecosystems function and how these notions applies to urban ecosystems can make planners to make sense how cities can contribute to ecologically sustainable interactions. And assist to acquire new abilities to overcome the limitations of mainstream planning models and perspectives to understand cities and regions not just as economic systems, or static inventories of natural resources, but also as socio environmental systems.

\section{References}

Ajutament de Barcelona. (2011). Plan del verde y de la biodiversidad de Barcelona 2020. Barcelona: Ajutament de Barcelona. Retrieved in 4 March 2016, from http://w110.bcn. cat/MediAmbient/Continguts/Documents/Documentacio/ PlandelVerdeyBiodiversidad_BCN2020_ESP.pdf.pdf

Allen, A. (2002). Urban environmental planning and management reviewed from a sustainability perspective: reform or transformation? L'Espace Geographique, 5(2), 1-34.

Beatley, T. (2010). Biophilic cities: integrating nature into urban design and planning. Washington: Island Press.

Bernard, J. (2014). Human watershed: the emerging politics of bioregional democracy. Retrieved in 4 March 2016, from http://www.kosmosjournal.org/article/human-watershedthe-emerging-politics-of-bioregional-democracy/

Best Foot Forward Ltd. (2002). City limits: a resource flow and ecological footprint analysis of Greater London. London. Retrieved in 15 March 2016, from http://www. citylimitslondon.com

Bettini, V. (1998). Elementos de ecología urbana. Madrid: Trotta.

Calthorpe, P., \& Van der Ryn, S. (1986). Sustainable communities: a new design synthesis for cities, suburbs and towns. San Francisco: Sierra Club.

Canada. Department of Communities, Land and Environment. (2016). Buffer zones. Prince Edward Island. Retrieved in 11 April 2016, from http://www.gov.pe.ca/environment/ bufferzones

Castro, H. (Ed.). (2002). Integración territorial de espacios naturales protegidos y conectividad ecológica en paisajes mediterráneos. Sevilla: Consejería de Medio Ambiente, Junta de Andalucía.

Centro de Información, Gestión y Educación Ambiental CIGEA. (2016, March 20). Gestion Ambiental. Cuba: CIGEA. Retrieved in 20 March 2016, from http://www.redciencia. $\mathrm{cu} /$ misionambiental/cigea.htm

Chapin, F. S., Matson, P. A., \& Mooney, H. A. (2002). Principles of terrestrial ecosystem ecology. New York: Springer Verlag. 
Devall, B., \& Sessions, G. (1985). Deep ecology: living as if nature mattered. Salt Lake City: Peregrine Smith Books.

Feria, J., \& Santiago, J. (2009). Funciones ecológicas del espacio libre y planificación territorial en ámbitos. Scripta Nova: Revista Electrónica de Geografía y Ciencias Sociales, 8(15), 299. Retrieved in 20 March 2016, from http://www. ub.es/geocrit/sn/sn-299.htm

Folke, C., Colding, J., \& Berkes, F. (2002). Building resilience for adaptive capacity in social-ecological systems. In F. Berkes, J. Colding, \& C. Folke (Eds.), Navigating socialecological systems: building resilience for complexity and change. Cambridge: Cambridge University Press. http:// dx.doi.org/10.1017/CB09780511541957.020.

Forman, R. (2014). Urban ecology: science of cities. Cambridge: Cambridge University Press.

Forman, R. T. T. (2008). Urban regions: ecology and planning beyond the city. New York: Cambridge University Press. http://dx.doi.org/10.1017/CB09780511754982.

Fritjof, C. (1997). The web of life: a new scientific understanding of living systems. New York: Anchor Books.

Geddes, P. (1915). Cities in evolution. London: Williams and Norgate.

Grimm, N. B., Faeth, S. H., Golubiewski, N. E., Redman, C. L., Wu, J., Bai, X., \& Briggs, J. M. (2008). Global change and the ecology of cities. Science, 319(5864), 756-760. PMid:18258902. http://dx.doi.org/10.1126/science.1150195.

Grimm, N., Morgan Grove, J., Pickett, S. T. A., \& Redman, C. L. (2000). Integrated Approaches to Long-Term Studies of Urban Ecological Systems. Bioscience, 50(7), 571-584. http://dx.doi.org/10.1641/0006-3568(2000)050[0571:IA TLTO]2.0.CO;2.

Gunderson, L. (2000). Ecological resilienc in theory and application. Annual Review of Ecology and Systematics, 31(1), 425-439. http://dx.doi.org/10.1146/annurev. ecolsys.31.1.425.

Haines-Young, R. H., \& Potschin, M. B. (2009). Methodologies for defining and assessing ecosystem services. Nottingham: Centre for Environmental Management University of Nottingham. Final Report.

Holling, C. (1973). Resilience and stability of ecological systems. Annual Review of Ecology and Systematics, 4(1), 1-23. http://dx.doi.org/10.1146/annurev.es.04.110173.000245.
i-Tree. (2016). Analysis tools. Retrieved in 16 March 2016, from http://www.itreetools.org/

Jones, C., Baker, M., Carter, J., Jay, S., Short, M., \& Wood, C. (2006). Strategic environmental assessment and land use planning: an international evaluation. London: Routledge.

Light, J. S. (2009). The nature of cities: ecological visions and the american urban professions 1920-1960. Baltimore: University Press.

Makropoulos, C., Rozos, E., Bruaset, S., Frijns, J., \& Van Der Zouwen, M. (2012). Best practices for sustainable urban water cycle systems. GWP. Retrieved in 11 March 2016, from http://www.gwp.org/Global/ToolBox/References/ Best $\% 20$ Practices\%20for\%20Sustainable\%20Urban\%20 Water\%20Cycle \%20Systems\%20\%E2\%80\%93\%20 TRUST\%20\%282012\%29.pdf

Marsh, K. (1999). Basic concepts in environmental management. New York: Lewis Publishers.

Marten, G. (2008). Human ecology: basic concepts for sustainable development. London: Earthscan.

Marzluff, J., Shulenberger, E., Endlicher, W., Alberti, M., Bradley, G., Ryan, C., Zum Brunnen, C., \& Simon, U. (2008). Urban ecology: an international perspective on the interaction between humans and nature. New York: Springer. http:// dx.doi.org/10.1007/978-0-387-73412-5.

McDonnell, M. J., Hahs, A. K., \& Breuste, J. H. (2009). Ecology of cities and towns: a comparative approach. New York: Cambridge University Press. http://dx.doi.org/10.1017/ СB09780511609763.

McHarg, I. L. (1967). An ecological method for landscape architecture. Landscape Architecture, 57, 105-107.

Miller, K. (1999). What is bioregional planning? In COMISIÓN ECONÓMICA PARA AMÉRICA LATINA - CEPAL. Estrategias ambientales para el desarrollo sustentable de América Latina y el Caribe: 2000 - Fundamentos territoriales y bioregionales de la planificación. Santiago de Chile: CEPAL.

Mostafavi, M., \& Doherty, G. (2010). Ecological urbanism. Baden: Lars Müller Publishers.

Mumford, L. (1968). The urban prospect. New York: Harcourt Brace Jovanovich.

Newman, P., \& Jennings, I. (2008). Cities as sustainable ecosystems: principles and practices. Washington: Island Press. 
Odum, E. P. (1983). Basic ecology. Filadelfia: Saunders College Publishing.

Organización de las Naciones Unidas para la Alimentación y la Agricultura - FAO. (2015). Agricultura urbana y periurbana en América Latina y el Caribe. Rome: FAO. Retrieved in 4 March 2016, from http://www.fao.org/ag/ agp/greenercities/es/CMVALC/ciudad_de_mexico.html

Orr, D. (1992). Environmental literacy: education as if the earth mattered. Bristol: E. F. Schumacher Lectures.

Owen, D. (2009). Green metropolis : why living smaller, living closer, and driving less are the keys to sustainability. New York: Penguin Books.

Pickett, S. T., Cadenasso, M. L., Grove, J. M., Boone, C. G., Groffman, P. M., Irwin, E., Kaushal, S. S., Marshall, V., McGrath, B. P., Nilon, C. H., Pouyat, R. V., Szlavecz, K., Troy, A., \& Warren, P.. (2010). Urban ecological systems: scientific foundations and a decade of progress. Journal of Environmental Management, 92(3), 331-362. PMid:20965643. http://dx.doi.org/10.1016/j.jenvman.2010.08.022.

Reed, C., \& Lister, N. (2014). Projective ecologies. Massachusetts: Harvard University Press.

Rees, W. (1996). Indicadores territoriales de sustentabilidad. Ecología Política, 12, 17-25.

Rosales, N. (2015). Walking the path to urban sustainability: what is still missing in current urban planning models? In A. Allen, M. Swilling \& A. Lampis (Eds.), Untamed urbanisms. London: Routledge.

Spirn, A. W. (1984). The granite garden: urban nature and human design. New York: Basic Books.

Spirn, A. W. (2013). Ecological urbanism: a framework for the design of resilient cities. In S. T. A. Pickett \& M. Stone (Eds.), Applying ecological principles. The Center for Ecoliteracy. Retrieved in 14 April 2015, from http:// www.ecoliteracy.org/article/applying-ecological-principles

Taylor, B. (2000). Bioregionalism: an ethics of loyalty to place. Landscape Journal, 19(1-2), 50-72. http://dx.doi. org/10.3368/lj.19.1-2.50.
Terradas, J. (2001). Ecología urbana. Barcelona: Rubes Editorial.

The Commission for Environmental Cooperation - CEC. (2016). The North American Environmental Atlas. Retrieved in 6 April 2016, from http://www.cec.org/tools-and-resources / north-american-environmental-atlas

Tjallingi, S. (1995). Ecopolis: strategies for ecologically sound urban development. Leiden: Backhuys Publishers.

Tomera, A. (2001). Understanding basic ecological concepts. Portland: J. Weston Walch.

Treebaltimore. (2016). Value of Baltimore's trees. Retrieved in 12 March 2016, from http://www.treebaltimore.org/

United Nations Environmental Programm - UNEP-IETC. (2003). The ecosystems approach to urban environmental management. Nairobi: United Nations Environmental Programme.

Van der Ryn, S., \& Cowan, S.(1996). Ecological design. Washington: Island Press.

Warren, R. (2013). Practice of sustainable community development: a participatory framework for change. New York: Springer.

Wittig, R. (2009). What is the main object of urban ecology? Determining demarcation using the example of research into urban flora. In M. J. McDonnell, A. Hahs, \& J. Breuste (Eds.), Ecology of cities and towns: a comparative approach. New York: Cambridge University Press. http://dx.doi. org/10.1017/CB09780511609763.031.

World Watch Found - WWF. (2011). Manejo del agua en cuencas hidrograficas: desarrollo de nuevos modelos, informe final. Mexico: World Watch Found.

Zipperer, W. C., Sisinni, S. M., Pouyat, R. V., \& Foresman, T. W. (1997). Urban tree cover: an ecological perspective. Urban Ecosystems, 1(4), 229-247. http://dx.doi. org/10.1023/A:1018587830636.

Received: Dec. 20, 2015

Approved: July 19, 2016 